\title{
Sustainability OF SUPPLy CHAINS IN COSTA RICA FOCUSING ON FREIGHT TRANSPORTATION EMISSIONS
}

\author{
Natalia Robles ${ }^{1}$ \\ ${ }^{1}$ Department of Industrial Production Engineering, Instituto Tecnológico de Costa Rica, \\ Cartago, Costa Rica
}

\begin{abstract}
This paper explores sustainability in supply chains in Costa Rica through an overview of the industrial sector and identifies its most common characteristics. Moreover, relying on the carbon footprint indicator and using estimates of the carbon emissions from a supply chain network, mainly associated with transportation, arrives at the conclusion that they should be carefully examined to promote initiatives of sustainability and to reduce the carbon footprint in accordance to the government's intention to become carbon neutral by 2021. Throughout the research it was found that the old rail infrastructure from the central plateau to the ports is rather attractive to reduce carbon emissions. The paper also presents options to achieve sustainability and points out challenges that must be overcome denoting the deficient transportation infrastructure as the most critical. The aim of this work is to call attention to the need to undertake a plan for freight transportation suitable to reduce emissions and secure sustainability.
\end{abstract}

\section{Keywords:}

Sustainability, Supply chains, Carbon footprint, Freight transportation, Carbon Emissions

\section{INTRODUCTION}

Sustainability is a concept recently incorporated to businesses and even later to supply chains which has been evolving rapidly in the last years. Payman and Searcy (2013) [1] state that it has been defined in several ways, as the capability of creating resilient organizations able to affront adversity, by means of economical, environmental and social integrated systems, having initiatives as corporate sustainability or corporate social responsibility, and emphasizing the role of supply chain management. Therefore sustainability in the supply chain is a current concern for many companies. Some have already measured their carbon emissions and taken steps to determine the carbon footprint in organizations and products, although it still is not a regular practice. The carbon footprint has been used as an indicator of the environmental impact of the supply chain, towards its sustainability, with the advantage of being a simple and easy to understand indicator though limited to define the overall environmental impact of a product. Various methodologies have been presented for carbon footprint accounting such as: PAS 2050, from Great Britain, BPX30-323, from France, the ISO 14040/44, and the GHG Protocol from the World Resource Institute (WRI) and the World Business Council for Sustainable Development (WBCSD).

Seman et al. (2012) [2] concluded that more research on green supply chains implementation and adoption is needed in developing countries. Developing countries urge to have more sustainable production operations and products. The products distribution and transportation is in fact an important decision in supply chains in order to assure not only customers satisfaction but also 
resources efficiency (Negi and Anand, 2015) [3]. In this paper a developing country supply chains characteristics and freight transportation conditions are studied to propose suitable strategies and options to reduce carbon emissions and to achieve sustainability. It is envisioned that the findings related to freight transportation and sustainable supply chains in this research will be useful to other similar developing countries determined to pursue a more sustainable state.

\section{LITERATURE REVIEW}

Hong et al. (2009) [4] confirm that the increment in the level of environmental requirements impacts the nature of the collaboration efforts among suppliers and distributors. Tiwari et al. (2013) [5] indicate that many supply chain management strategies consider robust coordination and collaboration among their members, emphasizing that coordination among actors of the supply chain has implications at the level of sustainability. Van Hoof and Thiell (2013) [6] found that sustainability requires multi-interested demands; hence for implementing sustainable management, it is a must that the different actors have the ability to collaborate with each other. This collaboration may contribute to establish an inter-organizational platform where motivation may be achieved by goals such as cleaner production. Moreover, they concluded that collaboration is essential for the effective implementation of cleaner production; also that it may allow advances in terms of sustainable supply chains. In brief, they confirmed cleaner production is a first step towards supply chain sustainability.

It is important to highlight that some companies' economic goals also promote sustainability. One example is the search for waste elimination in operative processes. Martínez-Jurado and Moyano-Fuentes (2013) [7] indicate that lean and green concepts are complements that are governed by principles of waste reduction centered on the process, preventive actions, as well as in high levels of worker participation. They point out that lean companies have created opportunities to apply principles of green manufacturing which in addition to lean practices favor the achievement of environmental improvements. They emphasize that one of the hardest challenges of companies involved with lean initiatives is to achieve integration with key suppliers and clients.

Arvis et al. (2014) [8] indicated that the concern for sustainable supply chains has increased mainly in developed countries. For that reason developing countries when commercializing with developed countries need to carefully consider their logistic print and review their governmental models and operations to ascertain that they have the best infrastructure with transportation modes, mainly rail, because although supply chains do expand and cover several countries they still are critical for a nations' competitiveness. Testa and Iraldo (2010) [9] highlight that companies today go beyond the limits of their production processes and organizations, they focus on the life cycle of their products and services, that is, on their supply chain. Hence, sustainable supply chains must quantify the impacts of all the links and collaborate among them in order to reduce their overall impact. The actual concern for life cycle analysis demands collaboration among actors, and the impact of a not-committed actor is worth to be avoided.

Beamon (1999) [10] points out that the first step attaining sustainability in the supply chain is to redefine its structure, adding environmental concerns such as resources utilization and waste. States also, that the traditional supply chain must be extended to recover the product; despite of the fact that this extension may add complexity to its structure. That in addition, this extension would have its own issues such as the unknown product return or packaging rates and the management of the inverse logistics considering that recollection, transport and packaging could affect the current facilities location, inbound logistics and environmental development. Deshmukh and Vasudevan (2014) [11] indicate that extension of the supply chain demands to 
rethink performance indicators including supplier selection criteria in order to allow companies to achieve sustainability but remain in the market.

\section{OBJECTIVES OF THE STUDY}

Carbon emissions are critical today, the Intergovernmental Panel for Climate Change IPCC (2014) [12] indicates that the scientific community is demanding to take the net emissions of greenhouse gases to zero by 2100 , and urged nations, mainly developed ones to intensify efforts in that sense. Costa Rica is committed to become carbon neutral by 2021 and one of the highest carbon emission sources is transportation. Hence the present study has been conducted with the following objectives:

-Identify characteristics of the supply chain networks in the country.

-Suggest strategies suitable to reduce carbon emissions mainly for freight transportation.

-Suggest supply chain network options to achieve sustainability.

-Identify challenges the country must overcome to achieve sustainability in supply chains.

\section{Methodology}

In order to identify supply chains in Costa Rica and their characteristics a descriptive research methodology was conducted identifying the most representative industry sectors.

To illustrate the impact of freight transport effectiveness and the need to reduce carbon emissions, several cases of freight transportation are presented. Since diesel is the common fuel the emission factor for carbon dioxide of $2.69 \mathrm{~kg} \mathrm{CO}_{2} \mathrm{e} / \mathrm{liter}$ as specified in 2014 by the National Meteorological Institute IMN (which is in accordance with the value of the GHG Protocol 2014) will be used. Other greenhouse gases that result from fuel combustion are $\mathrm{CH}_{4}$ and $\mathrm{N}_{2} \mathrm{O}$, the National Meteorological Institute IMN (2014) [13] reports them only for diesel operated vehicles that lack a catalytic converter. Those three gas emissions need to be converted to carbon equivalent emissions using the warming potential factors projected to 100 years as denoted by IPCC (Intergovernmental Panel on Climate Change). In this study, even assuming vehicles without catalytic converters, $\mathrm{CH}_{4}$ and $\mathrm{N}_{2} \mathrm{O}$ emissions were found to have a very small influence on the overall results, because $\mathrm{CO}_{2}$ emissions prevail.

Currently freight transportation modes were considered in the calculations for the cases studied. Common fleet characteristics in the country were also considered in the cases. Distances and routes were obtained from government reports. The fuel economy data for calculations was taken from available recent research.

Based on the results obtained, and considering state of the art practices from the literature review, as well as the characteristics of the supply chains of the country, options for possible supply chain networks are suggested to achieve sustainability.

\section{RESULTS AND DISCUSSION}

\subsection{Supply Chain Networks in Costa Rica}

Pursuing the objectives of this research thru a broad overview of the Costa Rican industry practices several supply chain network characteristic were encountered. 


\subsubsection{Supply Chain Networks Characterization}

Cimoli (2005) [14] indicates that national industries in Costa Rica export mostly food and traditional manufacture which consist of agriculture products of low value added. There are well established agricultural-chains such as the coffee, milk, banana and pineapple chains. In regard to milk, the Agriculture Livestock and Dairy Ministry MAG (2013) [15] reported that $43 \%$ of the farms are specialized in milk production and of them more than $86 \%$ are small (less than 50 hectares). The remaining $57 \%$ are meat and milk farms. The purchasers of milk in the country are only eight milk processing plants, which distribute within the country $55 \%$ of the production, constituting, therefore, an oligopolic structure. There are cooperatives and private capital companies, with a high level of integration with the agricultural production, characterized by the acquisition of raw materials throughout the whole year. CEPAL (2014) [16] found that the dairy value chain in Costa Rica presents a high level of integration of small and medium enterprises, that have been able to maintain their competitiveness even confronting the additional costs motivated by the environmental measures taken to differentiate their products, precisely to guarantee environmental development, achieving that way the highest milk exportation in Central America. Cooperativa de Productores de Leche Dos Pinos, the main producer, has two production plants and eleven distribution centers in the country.

With regard to the pineapple supply chain, Barrientos y Porras (2010) [17] found that plantations have grown substantially in the last decades and today about $90 \%$ of the production is exported. There are many medium and small producers that have given rise to a variety of affiliate organizations, companies and even cooperatives, dedicated to packaging and other related activities. The exportation mode is mainly by sea, from the port at Limón, which implies transportation of the product by land from the farms and packaging companies of some $75 \mathrm{~km}$ in the best cases, but if they come from the region of Buenos Aires (Puntarenas), south of the country, where one of the major producers is located the distance increases to $350 \mathrm{~km}$ approximately.

Another consolidated supply chain sector refers to supermarkets. The Chamber of Commerce of Costa Rica (2013) [18] concluded that the distribution chain of food products to warehouses, supermarkets and small and medium size convenience stores is well developed and that there are even supermarket chains that import directly. They also observed that certain multinational and transnational consumer goods companies control their distribution channels with great emphasis in placing their brands in the market, and even do by themselves the distribution operations of their own products.

Food and beverages is another important production and exportation industrial sector of Costa Rica. Some relevant companies produce and distribute their products through warehouses around the country; some others even have convenience markets of their own to sell their products (such as Florida Ice and Farm Company). However Hidalgo et al. (2009) [19] found that most food companies (medium and small) have suppliers within the country and subcontract their products distribution and commercialization services. Food manufactures usually lack warehouses and hence distribute products directly from their production plants.

Gil (2012) [20] shows that plastic exports increased $14 \%$ in 2010. Plastic manufactures range from national small companies to multinational giant companies usually located in free trade zones. All of them import the raw materials since they are not available in the country (Calderón et al. 2011) [21]. Exportations go mainly to Central America (55\%), USA (26\%) and the Caribbean (11\%), but there are also local clients, like food producers, to whom products are usually delivered directly from the plants. The pharmaceutical sector has also presented growth lately. Some companies of the pharmaceutical industry sector have modified their networks creating warehouses to cope with the expansion they have experienced. Other sectors such as the 
cement and concrete industries, have incremented the number of warehouses to achieve more penetration in the country.

It is important to remark that the structural reforms in Costa Rica have been characterized by an intense attraction of foreign investment by means of free trade zones. Matarrita (2004) [22] reported that despite that policy, companies of the medical industry, high technology electronics and various similar services, purchase as little as $7 \%$ of their materials within the country while import more than 70\%. Cimoli (2005) [14] reported that only $36 \%$ of the national suppliers are local producers, $47 \%$ are intermediaries and $13 \%$ are just service suppliers. They conclude that the attraction of foreign direct investment has increased the total exportation values of the country but has not established backward chains and has not been able to steer the country to a cultural transformation. CEPAL (2014) [16] remarks that Latin America is not an important goods supplier for North American chains and is not even an important importer of relevant intermediate goods from its own countries.

\subsubsection{Transportation Infrastructure Characterization}

Most manufacturing companies in the country distribute their products from their plants directly to clients or retailers, with short delivery frequencies, even daily and more so in the case of massive consumer products. These delivery practices, which also take place in medium size companies, have impacts that need to be further studied because even though the territory is small, the country endures today high levels of occupation in the central plateau, which are causing high congestion in road transportation. Herrera-Murillo et al. (2014) [23] found that the vehicle fleet increased uninterruptedly at an annual rate of 13.3\% during the period of 2001-2009 and continues with a similar tendency. Private transit has been growing at an annual rate of $8 \%$, however the road infrastructure has not been upgraded at the same rate, given rise to saturation. This high transit congestion results in fuel waste, high vehicle operating costs, lost time for users, and other serious effects. CEPAL/OCDE/CAF (2013) [24] pointed out that Costa Rica is afflicted by lack of road infrastructure, suitable customs facilities and logistics services, where transportation constitutes its main weakness, mainly due to the poor condition of the roads. It is also important to remark that the rail infrastructure for freight is rather old; there is only an obsolete infrastructure to the Pacific and Caribbean ports of 116 and $163 \mathrm{~km}$, which in the last 20 years has been almost unused and abandon. There have been recent improvement efforts to reverse this condition but still severe problems need to be resolved. In addition, the irregular topography of the territory complicates actions for improvement. Moreover, from an economical perspective, the aspects just mentioned increase goods transportation costs which being elevated worsen the competitiveness of the country. This issue has even hindered the expansion of manufacturing plants in the country. Barquero (2014) [25] indicates that Costa Rican companies add transportation costs to the motives for their expansion out of the country, such as some recent investments done in Nicaragua. Even more, CONARE (2014) [26] in the State of the Nation Report revealed that factory owners feel that the main triggers of production costs in the country are electricity and fuel prices. Osborne et al. (2014) [27] indicate transportation costs are high in all Central America because fuel costs are high, but also due to security reasons, empty containers travel, excessive travel time, and insufficient investment and credit for vehicle fleet modernization. Therefore the circumstances of the country in addition to the operative practices of companies are a challenge for its sustainability.

Furthermore, transport dedicated to product distribution contributes to contaminating emissions that affect the population's health. Ortiz (2011) [28] stressed that congestion and vehicles older than 18 years are responsible for pollution in the metropolitan area. They indicate that $45 \%$ of the vehicles from years 1993 and older emit $62 \%$ of the reactive organic gases and $42 \%$ of the nitrogen oxides. Herrera-Murillo et al. (2014) [23] concluded that transport vehicles are the main 
sources of air pollution especially in urban zones, where $28.1 \%$ of the units that use diesel as a fuel are years 1993 or older, thus lacking means for emissions control.

\subsection{Carbon Emissions from Freight Transportation}

Three cases were studied and calculations of their carbon emissions were performed.

The first case concentrates on the effects of transit congestion, characterized by poor fuel performance at low speeds.

The second case concentrates on the effects of freight weight in road transportation.

The third case concentrates on the effects and benefits of rail transportation.

\subsubsection{Case 1: Considering a light duty diesel 3 metric ton truck.}

If a vehicle travels with a performance (fuel economy) of $10 \mathrm{~km}$ per liter, in a $10 \mathrm{~km}$ distance it will require a liter of diesel and the resulting emissions would be: $2.69 \mathrm{~kg} \mathrm{CO}_{2} \mathrm{e}$.

Villegas and Camacho (2005) [29] research reported an average performance for light freight trucks in the country of $8.7 \mathrm{~km} / \mathrm{l}$ in 2004 . Thus, for the $10 \mathrm{~km}$ distance studied the resulting emissions could increase to $3.08 \mathrm{~kg} \mathrm{CO}_{2} \mathrm{e}$, (neglecting the effects of methane and nitrous oxide).

In a more dense traffic scenario the vehicles could experience even a lower performance, for instance if they were forced to decreased to $5 \mathrm{~km}$ per liter, for the same distance, the resulting emissions would increment to $5.38 \mathrm{~kg} \mathrm{CO}_{2} \mathrm{e}$.

Now, considering a portion of the General Cañas highway, where Herrera-Murillo et al. (2013) [23] reported a transit of 90 thousand vehicles on a day in 2011. Applying the above considerations for a $10 \mathrm{~km}$ distance with high congestion, where $20 \%$ of the vehicles could have a performance of $5 \mathrm{~km}$ per liter instead of $10 \mathrm{~km}$ per liter, where $19 \%$ of the fleet are light freight trucks, and from which 88\% use diesel (Villegas and Camacho, 2005) [29], the total emissions of this kind of trucks could have been 16.2 ton of $\mathrm{CO}_{2} \mathrm{e}$ per day rather than 8.1 ton of $\mathrm{CO}_{2} \mathrm{e}$ if they would have been able to travel at the desired speed and performance. In addition to these emissions that affect climate change, other pollutants emitted during combustion degrade the quality of air, especially those from vehicles years 1993 and older that were not compelled to incorporate means to diminish them.

Susuki (2010) [30] remarks that fuel consumption is affected by factors such as vehicle speed and road gradient in addition to distance traveled. Huai et al. (2006) [31] mentioned that several engine and vehicle parameters such as engine revolutions; load, vehicle average speed and time while idle affect emissions. Brodrick et al. (2012) [32] reported that higher engine speeds, as well as higher accessory loading (such as air conditioning) even when trucks are idle, increase fuel consumption and as such increase their emissions. Therefore for more precise estimations these additional factors would need to be accounted.

\subsubsection{Case 2: Considering a heavy duty 40 metric ton truck.}

Costa Rica exports mostly food and agriculture products of low value added. Pineapple plantations have grown substantially in the last decades and today most of the production is exported. Pineapples are primarily exported through Limon, the Caribbean Port of the country. However, they are grown far from the coast and must travel by truck to that port, in some cases as much as $350 \mathrm{~km}$. Considering that heavy duty 40 ton diesel trucks carry out these deliveries, and using Villegas and Camacho (2005) [29] performance report for that type of trucks in the country, (where in the interviews half of the drivers affirmed performances of $1.8 \mathrm{~km} / \mathrm{l}$ ), 
emissions would be of the order of $523 \mathrm{~kg} \mathrm{CO}_{2} \mathrm{e}$ per truck per one way trip. Huai et al. (2006) [31] states that performances vary year to year, but several studies have used a performance of $2.8 \mathrm{~km} / \mathrm{l}$ for heavy duty diesel trucks (classes 4 to 8 ). Similarly, the GHG Protocol emission factor tables for freight transportation in USA and other regions (taken from EPA) denote emissions of heavy duty trucks to be based on performances varying from 2.5 to $5 \mathrm{~km} / \mathrm{l}$. Consequently, an average performance of $1.8 \mathrm{~km} / \mathrm{l}$ will be considered applicable in this study, even though it may be higher or lower depending on the factors previously mentioned.

Considering that most trucks may return empty once delivery is accomplished, in order to pick up more product, fuel performance should be higher due to the reduction in load over the return trip, and if all other factors remain similar (slopes, speeds, distance) emissions should be less. It is important to mention that DEFRA (2012) [33] stated that efficiency changes due to freight transportation are visible mainly in big trucks. In their study they found that when big trucks are loaded to their full capacity they have emissions $25 \%$ more than when they travel half loaded and when they are unloaded emissions may be 25\% less. Leduc (2006) [34] explains fuel consumption in heavy duty trucks was found to increase linearly with the load carried. According to his data fuel consumption incremented 60 to $65 \%$ when trucks were fully loaded as compared to when they were travelling empty. Thus, for the return trip of the truck with the empty container a fuel performance is estimated in $2.7 \mathrm{~km} / \mathrm{l}$, from which the resulting emissions (for the return trip of $350 \mathrm{~km}$ ) are $348.7 \mathrm{~kg} \mathrm{CO}_{2} \mathrm{e}$ and thus emissions for the round trip would be about $871.7 \mathrm{~kg} \mathrm{CO}_{2} \mathrm{e}$.

In 2013 total pineapple exports amounted to 1,939,680 ton (Boeglin, 2015) [35] of which the production from a plantation in Buenos Aires (Puntarenas) constituted approximately 20\%, that is, about 388 thousand ton. Considering that a typical truck can carry about 18 tons of pineapples, (with a total weight of some 40 tons, including the weight of the pineapple boxes and the container of about 3.5 tons) over 21 thousand truck trips would be needed to take the fruit to port each year. In so doing, they will emit about 19 million ton of $\mathrm{CO}_{2} \mathrm{e}$ per year including their return trip to the producer's plant. Therefore, the need to reduce emissions is quite evident, either by improving truck's fuel efficiency, or else by introducing other more convenient transportation modes. It is important to remark that pineapple transportation has some other issues such as refrigeration, which must be considered when estimating carbon emissions for the entire supply chain footprint.

\subsubsection{Case 3: Considering intermodal transportation using railroad trains and trucks}

Even though in the past (for over 100 years) a railroad system connected the central plateau to the Atlantic coast, currently the train transports only banana and iron mostly within the coastal area. The following calculations are aimed to estimate the reduction that could be achieved by introducing rail transportation for pineapple exports. It will be considered that the freight is taken all the way to San Jose by truck and from there to Limón by train, figure 1 shows an overall view of the target locations but not of the actual routes. It is also possible to get the fruit to a closer point and thus reduce both the truck and train travel distances in about $20 \mathrm{~km}$. A train with a capacity equivalent to that of 20 trucks will be assumed. The distance from Buenos Aires to San José is about half of the distance by truck to the Port of Limón $(195 \mathrm{~km})$, hence emissions using heavy duty trucks with a fuel economy of $1.8 \mathrm{~km} / \mathrm{l}$ following the same procedure presented in case 2 yield the results shown in table 1 . The emission factor for rail transportation given in the GHG Protocol 2014 is $0.0285 \mathrm{~kg} \mathrm{CO}_{2} / \mathrm{ton}-\mathrm{km}$ (for UK) and since the distance from there to the Port is $163 \mathrm{~km}$, rail travel emissions result in $2090 \mathrm{~kg} \mathrm{CO}_{2} \mathrm{e}$. The return trip of the train with the empty containers, involves a smaller load for which emissions are estimated at about $15 \%$, see table 1. Maximilian and Wilmsmeier (2014) [36] reported a higher emission factor for rail transportation in Latin America, $0.04 \mathrm{~kg} \mathrm{CO}_{2} / \mathrm{ton}-\mathrm{km}$, which if used increments the emissions in $40 \%$. Table 1 presents all the results. 
International Journal of Managing Value and Supply Chains (IJMVSC) Vol. 7, No. 1, March 2016

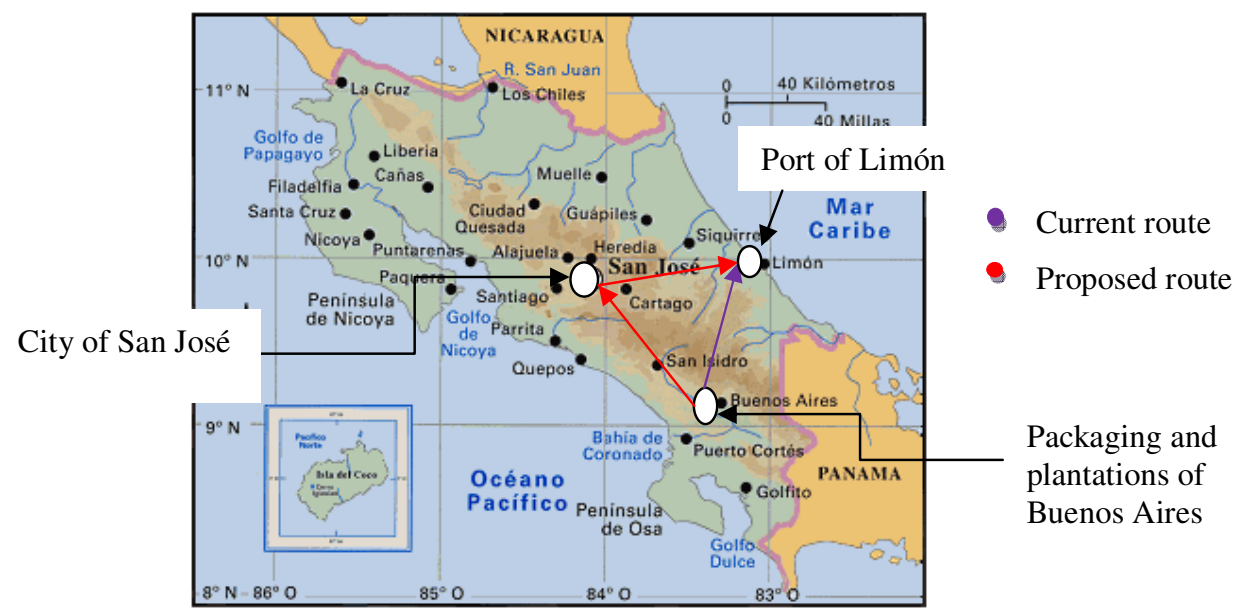

Figure 1. Locations considered for case 3

Table 1. Results of carbon emissions $\left(\mathrm{kg} \mathrm{CO}_{2} \mathrm{e}\right)$ for different transportation modes, loads and distances traveled.

\begin{tabular}{|c|c|c|c|c|c|}
\hline $\begin{array}{l}\text { Departure } \\
\text { Location }\end{array}$ & Mode & $\begin{array}{l}\text { Load carried } \\
\text { (ton) }\end{array}$ & $\begin{array}{c}\text { Arrival } \\
\text { Location }\end{array}$ & $\begin{array}{c}\text { Distance } \\
(\mathbf{k m})\end{array}$ & $\begin{array}{c}\text { Emissions } \\
\mathrm{kg} \mathrm{CO}_{2} \mathrm{e} \\
\text { (round trip) }\end{array}$ \\
\hline \multirow[b]{2}{*}{$\begin{array}{l}\text { Buenos } \\
\text { Aires }\end{array}$} & 1 Truck $^{1}$ & 19 & \multirow[b]{2}{*}{ Port of Limon } & 350 & 871.7 \\
\hline & $\begin{array}{c}20 \\
\text { Trucks }\end{array}$ & 380 & & 350 & 17434 \\
\hline \multirow{2}{*}{$\begin{array}{l}\text { Buenos } \\
\text { Aires }\end{array}$} & 1 Truck & 19 & \multirow[b]{2}{*}{$\begin{array}{l}\text { City of San } \\
\text { José }\end{array}$} & 195 & 485.7 \\
\hline & $\begin{array}{c}20 \\
\text { Trucks } \\
\end{array}$ & 380 & & 195 & 9714.7 \\
\hline \multirow{2}{*}{$\begin{array}{l}\text { City of San } \\
\text { José }\end{array}$} & 1 Train $^{2}$ & 380 & \multirow{2}{*}{ Port of Limon } & 163 & 2415.2 \\
\hline & 1 Train $^{3}$ & 380 & & 163 & 3390 \\
\hline
\end{tabular}

Notes: ${ }^{1}$ Trucks are assumed to have a fuel economy of $1.8 \mathrm{~km} / 1$ with full load and $2.7 \mathrm{~km} / 1$ in their return trip. ${ }^{2}$ The emission factor for this train is $0.0285 \mathrm{kgCO}_{2} /$ ton-km). ${ }^{3}$ The emission factor for this train is $0.04 \mathrm{kgCO}_{2} /$ ton-km.

The carbon emissions result in 12131 or $13104 \mathrm{~kg} \mathrm{CO}$ e for the train with trucks option, depending on the train's fuel efficiency used. It is more than evident that these emissions are much lower than the emissions that result for the option where only trucks are used of $17434 \mathrm{~kg}$ $\mathrm{CO}_{2} \mathrm{e}$.

Villegas and Camacho (2005) [29] reported that freight rail transportation in Costa Rica, required in 2004168368 liters of diesel, transported 254374 ton of product (banana and iron) and traveled $60550 \mathrm{~km}$. From the total fuel consumption reported, total carbon emissions are estimated to be 453 ton $\mathrm{CO}_{2} \mathrm{e}$ for that year. The fuel economy from that same data is estimated in $2.78 \mathrm{l} / \mathrm{km}$, and the average load transported in 260 tons. From the fuel efficiency an emission factor of $7.5 \mathrm{~kg}$ $\mathrm{CO}_{2} \mathrm{e} / \mathrm{km}$ is derived for the train.

It's important to observe that rail transportation even when combined with trucks results in fewer emissions, with the data used for this study it is evident that at least a $25 \%$ reduction can be achieved. Therefore a train, even with limitations as depicted here, used as an intermodal transportation mode, results attractive to lower emissions. There are concerns to be resolved though, such as the significant difference in altitude between the central plateau and the coast, but also benefits as the convenience of employing electricity as the energy source for the trains. 


\subsection{Options for Supply Chain Networks to Achieve Sustainability}

Supply chain network design includes decisions from the selection of raw material suppliers, manufacturing plants location, to product distribution strategies. Decisions that may affect sustainability in the whole chain and moreover in the products must be taken by each supply chain actor. Several companies around the world have modified their supply chain networks in order to improve their sustainability. Nagurney et al. (2013) [37] point out the case of Hennes \& Mauritz (H\&M) that identified more than half of their carbon footprint in 2009 was due to transportation operations and therefore decided to make several changes, they increased direct transportation and eliminated intermediate warehouses, reduced their overseas and air transportation in $40 \%$, and incremented rail transport, in so doing they reduced their emissions significantly. According to the results obtained, a reduction of transportation carbon emissions in Costa Rica may also be achieved if rail transport is fully refurbished and expanded.

Some supply chain network modifications affecting outbound as well as inbound logistics may include the creation of warehouses. Warehouses are intermediate links between production plants and customers (Chopra and Meindl, 2012) [38]. They add operative costs and benefits but also emissions due to their operation and hence their benefits and disadvantages should be studied from the economical and environmental perspectives, a task for which the carbon footprint is a plausible indicator to be considered. Nagurney et al. (2013) [37] showed that the Sweden groceries chain ICA, modified their operations so that instead of each supplier delivering directly to each store in a small truck, now products are taken first to a warehouse from which they are sent as consolidated freight in a bigger truck to each store. Even though they incremented the freight indicator per kilometer, as the distances traveled are less, they achieve a reduction of about 20\% in emissions. Similarly, González (2014) [39] proposed that Costa Rica should create new alternatives to improve transport efficiency, such as the design and location of warehouses for important companies in key zones and according to the characteristics of each industrial sector. The Industries Chamber of Costa Rica (2013) [40] proposed that industry and the country as a whole should evolve to a green purchasing policy, that promotes eco efficiency and value chains, sustainable products, as well as adopt eco design instruments, and cleaner production. Therefore, the supply chain networks with all the actors and logistics operations involved has economical, environmental and societal impacts that need to be evaluated together to increase sustainability.

The following are options for improvement of the supply chain network extracted from this research and directed to achieve sustainability:

- Create warehouse facilities

- Close the supply chain loop

- Improve logistics operations

- Select new suppliers or alternative raw materials.

The above options differ from each other because they affect different actors of the supply chain and different operations through it. In addition, some may be difficult or even impossible to achieve, such as finding other suppliers for some raw materials. Others might depend considerably on the client behavior and culture, such as closing the loop of the supply chain with the creation of a reverse logistics structure. For that reason it is necessary to consider that a close loop supply chain could result in not only a difficult goal but even an impossible one, and hence it may or may not be the optimal condition to achieve sustainability. For instance, many companies, mainly of the food industry, have observed that their customers use the packages for 
a very short time and have decided to turn to bio degradable packing and now use mostly oxo degradable packages.

Other decisions such as improving logistics operations and creating links between manufacturing facilities and clients, with warehouses, are more operational. Warehouses could be subcontract or shared with other companies. Next figure presents the options in terms of the different actors of the supply chain they refer to.

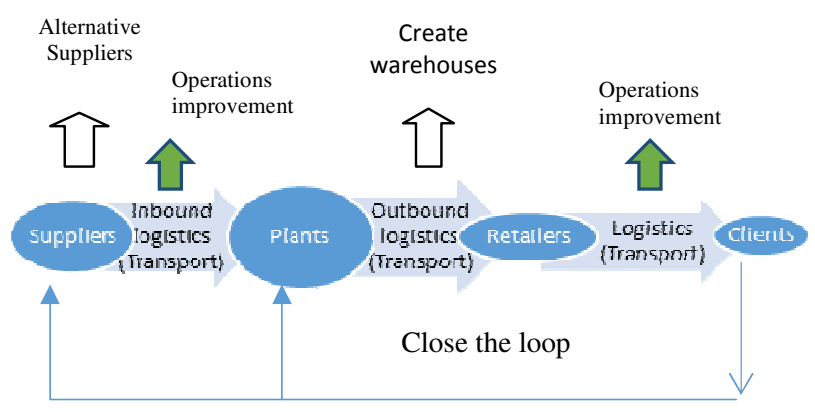

Figure 1. Supply chain network modification options

In brief, possible options for sustainability of supply chain networks have to be analyzed under the particular circumstances of each supply chain, taking into account benefits as well as limitations, in that sense indicators such as the carbon footprint turn out to be rather useful.

\subsection{Challenges to Achieve Sustainable Supply Chains in the Country}

Costa Rica must overcome the following challenges in order to achieve sustainability:

-It's imperative to introduce means to increment value added to products in the Costa Rican industrial sectors, as well as to establish more links with industries in Central America and further out.

-Road infrastructure needs to be drastically improved, and railroad facilities must be expanded and fully refurbished. Provide agile access to Industrial zones. Their development and location needs to be deeply studied, planed and regulated. The plan of the Industrial Chamber of Costa Rica (2009) [41] concluded that in order to evolve to a low carbon economy an effective territorial plan is required for companies and industrial zones, close to transportation roads and in so doing lower greenhouse gases emissions. Five years later this task has not been achieved though the country has the goal of becoming carbon neutral by 2021 .

-Transportation costs in the country urge to be reduced in order to improve competitiveness, in addition it is imperative to improve freight transportation, reduce empty truck displacement as well as travelling time.

-The complexity of the problems demands operative improvements that companies may undertake by their own to achieve cost reductions, but still some actions must be discussed and agreed between the industrial sectors and governmental instances due to their scope and complexity. 


\section{CONCLUSIONS}

Sustainability requires agreement among the economic, environmental and social interests. Businesses need to look after their profits and capability for expansion of their operations, but they must protect people and the environment. Several possible options, linked to network and operations within a supply chain must be analyzed to achieve a sustainable supply chain. A key factor is the need for more coordination among the actors.

Through several cases of typical product transportation in Costa Rica the effects in carbon emissions and carbon footprint were evaluated. Even though the calculations are based on data available from recent years, but perhaps not as complete and up to date as would be desirable, the results obtained demonstrate how sensitive the emissions are to transportation modes and efficiencies. For the agriculture product studied, the carbon emissions of transportation may be reduced when an intermodal transportation is used. In fact the calculations performed show that regular congestion in important industry highways in the country could increase emissions even in $75 \%$ when traveling across the more dense areas. Combining trucks with the current railroad infrastructure to the Port of Limón, pineapple transport emissions can be reduced in at least $25 \%$ as opposed to the present use of plain truck transportation.

Reducing carbon emissions from agricultural products exportation transport is highly important to lessen their overall carbon footprint, to make them more competitive in developed country markets, and to reduce national total emissions toward attaining carbon neutrality sooner. However this study shows that there is still much to be done in the country regarding transport infrastructure and operations, a well-defined emissions reduction plan has yet not been undertaken.

Although calculations favor rail as the transportation mode there are some other issues to be resolved such as flexibility, speed, and load capacity, which from the railroad companies' perspective, need to be further investigated with regard to maintenance and transportation costs they would have to assume. Obviously, there would be an undeniable need for the participation of other equally interested parties in the refurbishing and use of the train facilities. Thus actions to refresh the necessary data and proceed to enforce the corrective measures needed to lower carbon emissions, as well as to reduce transportation costs, must be fully and immediately undertaken by government.

It is evident that companies must incorporate carbon emissions calculations in their design studies for product distribution, freight volume and quantities, fleet routes, and distances that result from the supply chain network, especially massive consumption product companies. The value and convenience of using environmental indicators like the carbon footprint in each analysis is quite clear. Even though it is only an environmental indicator it can also be used to call attention to aspects that are important for human health.

To analyze the benefits of possible options for a supply chain, mathematical modeling results indispensable, since there may not be a unique set of conditions to follow, and moreover strategies may vary according to the supply chain studied.

Finally the actions and challenges highlighted in this research need to be taken into account by industry and government as a whole.

\section{FUTURE RESEARCH}

Other products with different characteristics should be studied more. 
International Journal of Managing Value and Supply Chains (IJMVSC) Vol. 7, No. 1, March 2016

\section{REFERENCES}

1. Payman, A.; Searcy, C. (2013) A comparative literature analysis of definitions for green and sustainable supply chain management. Journal of Cleaner Production, 52, 329-341. doi: doi:10.1016/j.jclepro.2013.02.018

2. Seman, N., Zakuan, N., Jusoh, A., Arif, M. \& Saman, M (2012) Green Supply Chain Management: A review and research direction. International Journal of Managing Value and Supply Chains, 3 (1). doi 10.5121/ijmvsc.2012.3101

3. Negi,S. and Anand,N. (2015) Issues and Challenges in the Supply Chain of Fruits and Vegetables Sector in India: A Review. International Journal of Managing Value and Supply Chains, 6 (2). doi 10.5121/ijmvsc.2015.6205

4. Hong, P., Kwon, H.B. y Roh, J.J. (2009) Implementation of strategic green orientation in supply chain. An empirical study of manufacturing firms. European Journal of Innovation Management, 12(4), 512-532. doi: 10.1108/14601060910996945

5. Tiwari M.K., Mahanty B., Sarmah, S.P. \& Jenamani, M. (2013) Modeling of Responsive Supply Chain. United States of America. CRC Press Taylor and Francis Group.

6. Van Hoof, B. y Thiell, M. (2013) Collaboration for sustainable supply chain management: small and medium sized enterprises in Mexico. Journal of Cleaner Production, 67, 239-248. doi: 10.1016/j.jclepro.2013.12.030

7. Martínez-Jurado, P.J. y Moyano-Fuentes,J. (2013) Lean Management, Supply Chain Management and Sustainability: A Literature Review. Journal of Cleaner Production. Retrieved from http://dx.doi.org/10.1016/j.jclepro.2013.09.042

8. Arvis, J.F., Saslavsky, D., Ojala, L., Shepherd, B., Busch, C. y Raj, A. (2014) Connecting to Compete Trade Logistics in the Global Economy The Logistics Performance Index and It's indicators. World Bank, Washington, DC. Retrieved from: https://openknowledge.worldbank.org/handle/10986/20399

9. Testa, F. \& Iraldo, F. (2010) Shadows and lights of GSCM (Green Supply Chain Management): determinants and effects of these practices based on a multi-national study. Journal of Cleaner Production, 18, 953-962. doi:10.1016/j.jclepro.2010.03.005

10. Beamon, B. (1999) Designing the green supply chain. Logistics Information Management, 12(4), 332-342. doi: http://dx.doi.org/10.1108/09576059910284159

11. Deshmukh, A.J. \&Vasudevan, H. (2014) Emerging Supplier Selection Criteria in the Context of Traditional vs Green Supply Chain Management. International Journal of Managing Value and Supply Chains, 5 (1). doi 10.5121/ijmvsc.2014.5103

12. Intergovernmental Panel for Climate Change IPCC (2014) Climate Change 2014: Synthesis Report Contribution of Working Groups I, II and III to the Fifth Assessment Report of the Intergovernmental Panel on Climate Change [Core Writing Team, R.K. Pachauri and L.A. Meyer (eds.)]. IPCC, Geneva, Switzerland, $151 \mathrm{pp}$.

13. Instituto Meteorológico Nacional IMN (2014) Factores de emisión GEI. Cuarta Edición. Retrieved from: http://cglobal.imn.ac.cr/documentos/factores-de-emision-gei-cuarta-edicion

14. Cimoli, M. (2005) Heterogeneidad estructural, asimetrías tecnológicas y crecimiento en América Latina. BID CEPAL Publicaciones ECLACS. pp. 1-162. Santiago, Chile. Retrieved from http://hdl.handle.net/11362/2799

15. Ministerio de Agricultura y Ganadería MAG (2013) Caracterización de la Agrocadena de Leche, Región Central Oriental. Biblioteca Virtual MAG. Retrieved from http://www.mag.go.cr/bibliotecavirtual/a00079.pdf

16. CEPAL Comisión Económica para América Latina y el Caribe (2014) Panorama de la Inserción Internacional de América Latina y el Caribe 2014: Integración regional y cadenas de valor en un escenario externo desafiante. ECLAC. Santiago. Retrieved from: http://hdl.handle.net/11362/37195 
International Journal of Managing Value and Supply Chains (IJMVSC) Vol. 7, No. 1, March 2016

17. Barrientos O. y Porras, S. (2010) Sector Agropecuario Cadena Productiva de Piña Políticas y Acciones. SEPSA MAG. Costa Rica. Retrieved from: http://www.infoagro.go.cr/MarcoInstitucional/Documents/Politica-Pi\%C3\%B1a.pdf

18. Chamber of Commerce of Costa Rica (2013) Canales de Distribución en Costa Rica.

19. Hidalgo, A., Herrera, R., López, V. \& Velásquez, G. (2009) El sector de la industria alimenticia en Costa Rica: una perspectiva desde la cadena de valor. Vicerrectoria de Investigación. Universidad de Costa Rica. Retrieved from http://catedrainnovacion.ucr.ac.cr/Ind\%20Alimentaria\%20Costa\%20Rica\%20\%20Cadena\%20de\%20Valor.pdf

20. Gil, J. (2012) Perfil de la industria en Costa Rica 2012. Retrieved from http://www.youblisher.com/p/291282-Perfil-de-la-Industria-en-Costa-Rica-2012/

21. Calderón, J., Chacón, M. y Gutiérrez, C. (2011) Mapeo Tecnológico Sector Plásticos Costarricenses. Promotora de Comercio Exterior de Costa Rica. PROCOMER. Costa Rica. Retrieved from: http://www.centralamericadata.com/docs/Documento_mapeo_tecnologico_sector_plastico_C.R..p df

22. Matarrita, R. (2004) Encadenamientos y Exportaciones. Undécimo Informe sobre el Estado de la Nación en el Desarrollo Humano Sostenible. Estado de la Nación en Desarrollo Humano Sostenible. Retrieved from: http://www.estadonacion.or.cr/files/biblioteca_virtual/011/Encadenamientos_exportaciones.pdf

23. Herrera-Murillo, J, Rojas-Marín, J. Rodríguez-Román, S. (2013) Evaluación de posibles medidas para reducir las emisiones de fuentes móviles en Costa Rica, 2010 -2015. Tecnología en Marcha. Vol-27. $\quad N^{\circ} 1 . \quad$ Pág. 23-37. Retrieved from http://tecdigital.tec.ac.cr/servicios/ojs/index.php/tec_marcha/article/view/176

24. CEPAL/OCDE/ CAF (2013) "Perspectivas Económicas para América Latina: Logística y Competitividad para el Desarrollo. OCDE Editorial. Paris. Retrieved from: http://hdl.handle.net/11362/1504

25. Barquero (2014) Empresas de Costa Rica aumentan sus inversiones en Nicaragua. La Nación. 6 de setiembre 2014. Retrieved from: http://www.nacion.com/economia/empresarial/EmpresasCosta-Rica-inversiones-Nicaragua_0_1437456257.html

26. CONARE Consejo Nacional de Rectores (2014) Capítulo 3: Oportunidades Estabilidad y Solvencia Económica. Informe Estado de la Nación 2014. Programa Estado de la Nación CONARE. Recuperado de http://www.estadonacion.or.cr/20/assets/cap-3-estado-nacion-20-2014baja.pdf

27. Osborne, T.; Pachon, M. and Araya, G. (2014) What Drives the High Price of Road Freight Transport in Central America?. World Bank, Washington, DC. () World Bank. Retrieved from: https://openknowledge.worldbank.org/handle/10986/18325

28. Ortiz, L. (2011) Carros “viejitos nos ahogan”. Semanario Campus UNA. Página 6. Costa Rica.

29. Villegas, G. and Camacho, M.A. (2005) Encuesta de consumo energético nacional en el sector transporte de Costa Rica año 2004. MINAE Dirección Sectorial de Energía. Costa Rica. Retrieved from: http://www.dse.go.cr/

30. Susuki, Y. (2010) A new truck-routing approach for reducing fuel consumption and pollutants emission. Transportation Research Part D, 16, 73-77. doi: 10.1016/j.trd.2010.08.003

31. Huai, T., Shah, S.D., Miller, J.W., Younglove, T., Chernich, D.J. \& Ayala, A. (2006) Analysis of heavy-duty diesel truck activity and emissions data. Atmospheric Environment. 40,2333-2344. doi: doi:10.1016/j.atmosenv.2005.12.006

32. Brodrick, C-J.,Lipman, T.E., Farshchi, M., Lutsey, N.P., Dwyer, H.A., Sperling, D., Gouse, S.W., Harris, D.B. and King, F.G. (2002) Evaluation of fuel cell auxiliary power units for heavy-duty diesel trucks. Transportation Research Part D. 7, 303-315. 
International Journal of Managing Value and Supply Chains (IJMVSC) Vol. 7, No. 1, March 2016

33. DEFRA Department for Environment Food and Rural Affairs (2012) Guidelines to Defra / DECC"s GHG Conversion Factors for Company Reporting: Methodology Paper for Emission Factors. London. UK. Retrieved from: www.defra.gov.uk

34. Leduc, G. (2006) Longer and heavier vehicles, an overview of technical aspects. JRC Scientific and Technical Reports. European Commision Joint Centre. Institute for Prospective Technical Studies. Luxembourg.

35. Boeglin, N. (2015) La piña de Costa Rica ante la Comisión Interamericana de Derechos Humanos. El País, UCR.

36. Maximilian F. A. and Wilmsmeier, G. (2014) Eficiencia energética y movilidad en América Latina y el Caribe. Una hoja de ruta para la sostenibilidad. CEPAL Naciones Unidas Chile. Retrieved from: http://hdl.handle.net/11362/36798

37. Nagurney, A.Yu, M. \& Floden, J. (2013) Supply chain network sustainability under competition and frequencies of activities from production to distribution. Computational Management Science 10:397-422. doi 10.1007/s10287-013-0190-6

38. Chopra, S. and Meindl, P. (2012) Administración de la cadena de suministro. Estrategia, Planeación y Operación ( $3^{\mathrm{a}}$.ed.). México. Pearson Educación.

39. González, G. (2014) Costa Rica en deuda con el desempeño logístico, El Financiero, 9 setiembre 2014. Retrieved from http://www.elfinancierocr.com/economia-y-politica/Costa-Rica-deudadesempeno-logistico_0_589141090.html

40. Industries Chamber of Costa Rica (2013) Hacia la empresa industrial del 2030. Propuesta para una política industrial. Retrieved from http://www.cicr.com/files/documentGallery/files/38_politica_industrial.pdf

41. Industries Chamber of Costa Rica (2009) Estrategia Industrial ante el Cambio Climático. Marco de la Alianza Público Privada (PPP) suscrita entre Cámara de Industrias de Costa Rica, Cámara Nacional de la Industria de Transformación de México y el Programa de Competitividad y Medio Ambiente (CYMA-GTZ). Retrieved from http://www.cicr.com/files/documentGallery/files/105_estrategiaindustrialanteelcambioclimtico.pd f 